\title{
Evaluation of the Latvian Financial Security: Aspects of Government Debt Policy
}

\author{
Nadezhda Semjonova, Riga Technical University
}

\begin{abstract}
Due to increased risk and severity of the global economic and financial crisis, the evaluation of financial security is vital for the national security. Internationally recognized indicators, such as sovereign credit ratings, may overestimate the actual situation due to political reasons. This paper presents a consolidated indicator of the state financial security, which takes into account a number of the state economic and financial parameters. The calculated indicator correlates well with the sovereign ratings for low rating values, but gives more pessimistic estimation for high ratings.
\end{abstract}

Keywords - Government debt, financial security, national security.

\section{INTRODUCTION}

National security is a complex of measures implemented by the state and the society to guarantee state independence, territorial integrity, constitutional rights, social development, prosperity and sustainability.

The concept of security is obviously broader than the notion of financial security, it includes military protection, information security, ecologic security, energetic independence, etc., but, nevertheless, there is no single aspect of the state security that would not depend on the state financial security. And, vice versa, financial security to a great extent depends on the other state security aspects.

It is pretty clear that financial independence is the one of the most important development aspects of the state fiscal policy. In the context of the present paper, financial security is seen as due arrangements of the state financial system, relationships and processes that provides pre-requisites to ensure financial stability and integrity of the state finances, neutralise threats to money stock, budget, taxes, and credits.

Recent sovereign debt crisis in Europe demonstrated extreme importance of the proper debt policy both in the context of debt accumulation and management.

Furceri and Zdzienicka [1] express an opinion that sovereign debt crisis impacts the state economy more negatively than banks or currency crises do. Moreover, the latter may be implicitly caused by sovereign debt crisis due to excessive national currency emission [2]. A number of authors emphasise the importance of the debt structure [3] - [8].

Sovereign credit ratings, assigned by the number of internationally recognized credit rating agencies, are worldwide acknowledged measures of the state financial security. Assignment of the rating always has considerable political consequences, whether the rating itself is good or not. A higher rating positively affects the country's reputation and opens a way toward better crediting conditions and broader involvement of foreign investments.
The most important state economic and financial indicators, contributing to the value of the sovereign ratings, are GDP growth rate, consumer price index, GDP per capita, total government debt, total external debt in particular economic sectors, state budget deficit / surplus, state balance of payments, foreign-exchange reserves, etc. [9]- [12]. Rating agencies evaluate political situation in the country as well. Nevertheless, credit ratings sometimes fail to evaluate the actual situation in the country, providing too optimistic view.

In the year 2011, the Saeima (the Parliament of the Republic of Latvia) approved the Conception of the National Security, where Clause 3.4 states on the counter-measures concerning threats to the state economic interests [13]. Unfortunately, this document defines the causes of potential threats, but does not provide any measure for their evaluation. The Review of the Financial Stability by the Bank of Latvia pays attention to the stability of the banking system only [14]. The above indicates the lack of consideration of the state financial stability as a whole.

There were some attempts to develop a method for the evaluation of the state financial safety. Ketners et.al proposed the use of the four parameters: inflation rate; government payment balance; government debt to GDP ratio; money stock to GDP ratio [15]. Such an approach does not take into account several important indicators. For instance, it ignores such parameter as share of external debt that seemingly played an important role in the recent financial crisis in Greece.

The aim of the present research is to develop a consolidated indicator that would take into account the parameters most relevant to the state financial security that could be used for independent and unbiased evaluation of the state financial stability.

\section{DATA AND METHODOLOGY}

Development of a single consolidated indicator for the evaluation of the state financial security required the selection of the contributing parameters. The search for these parameters was made by means of the content analysis. The pool of 108 randomly selected documents was used. The documents, selected by search on the keyword phrase "Government debt" were retrieved from the Science Direct and EBSCO databases and public web sites of the International Monetary Fund and rating agencies. The frequencies of the pre-defined keywords were calculates using "QDA Miner" software.

On the basis of the obtained frequencies tables, eight most important parameters were selected (Table I): The value of the debt itself, expressed in percent from GDP; the ratio of the 
debt service costs to the collected taxes; state budget deficit, expressed in percent form GDP; inflation level; long-term interest rate of the government bonds; external to the total debt ratio; debt per capita; money stock to GDP ratio.

Some of the above-mentioned parameters were listed in the Maastricht criteria - the set of rules that form a frame for country accession to the Eurozone.

Evaluation of the state financial security could be made by comparison of the corresponding parameter with some critical "threshold" value (Table I). Partially, such values were derived from the Maastricht criteria. For the level of the government debt, Maastricht criteria require the government debt to GDP ratio not to exceed $60 \%$. In the present work, the same threshold was used for external to total debt ratio and for money stock to GDP ratio. In the Maastricht approach, the threshold for the inflation rate was derived as average of the three best indicators among EU states plus 1.5 percent points, the same technique was used for the threshold of the long-term interest rate of the government bonds. Similar approach was used in the present work for the debt service costs to collected taxes ratio and for government debt per capita: the threshold was doubled average of the three best indicators in the EU. Details on the definition of the thresholds for the selected parameters are summarized in Table I.

TABLE I

THE STATE FINANCIAL SECURITY INDICATORS

\begin{tabular}{|c|c|c|c|}
\hline Nr. & Indicator & & $\begin{array}{c}\text { Indicator's } \\
\text { threshold }\end{array}$ \\
\hline 1 & Government debt / GDP & No more than & $60 \%$ \\
\hline 2 & $\begin{array}{c}\text { Interest (Government debt service } \\
\text { costs) / Collected taxes } *\end{array}$ & $* *$ & $\times 2$ \\
\hline 3 & $\begin{array}{c}\text { Government budget deficit / GDP } \\
\text { Inflation rate }\end{array}$ & $* *$ & +1.5 p.p. \\
\hline 4 & $\begin{array}{c}* * \\
\text { government bonds }\end{array}$ & +2 p.p. \\
\hline 6 & $\begin{array}{c}\text { External government debt / Total } \\
\text { government debt }\end{array}$ & & 60 \\
\hline 7 & Government debt / Population & $* *$ & $\times 2$ \\
\hline 8 & Money stock (M2) / GDP & No less than & $60 \%$ \\
\hline
\end{tabular}

*-without social insurance contributions (earmarked revenues)

** - average from the three best parameter values among the EU states.

The consolidated indicator for the evaluation of the state financial security is proposed in the form of

$$
X=\sum_{i=1}^{7} \frac{F_{i}}{R_{i}} \mu_{i}+\frac{R_{8}}{F_{8}} \cdot \mu_{8} \rightarrow \min ,
$$

where $F_{i}-$ is an actual value of the particular parameter; $R_{i}$ parameter's threshold value; $i$ - parameters' index in accordance with Table I; $\mu_{i}$ - parameter's weight factor, $\sum \mu_{i}=1$.

The value of the consolidated indicator $X$ is equal to 1 if all parameters coincide with their recommended thresholds. As the financial situation improves, the indicator decreases and tends to zero.

Weight factors $\mu_{i}$ for each contributing parameters were obtained via expert opinion analysis. The expert pool was composed from both academicians and professionals from various state and private bodies, operating in the areas of government debt politics and state debt management. Experts were asked to rank the parameters from Table I in order of importance for the state financial security. No equal ranks were allowed. Totally 39 questionnaires were received: 32 from academic personnel of the Latvian universities (Riga Technical University, University of Latvia; Latvian Agriculture University) and 7 from professionals from Latvia, Spain, Slovakia, Slovenia and Switzerland.

The inter-expert agreement was evaluated using Kendall's coefficient of concordance $W$ [16]. The coincidence among experts was interpreted as high when $\mathrm{W}$ was higher than 0.64. The significance of $W$ was evaluated too, by the $\chi^{2}$ criterion [17]: for the significant $W$ empirical $\chi^{2}>\chi^{2} \mathrm{kr}$. In the present work, $\chi^{2}$ kr was 14.1 that corresponded to the significance level 0.05 .

The ranks assigned by the experts were transformed into weights using linear scale (Table II). Transformation was required, because the parameter with highest, first rank has to have biggest weight.

TABLE II

SECURITY INDICATOR'S RANK - TO - WEIGHT RECALCULATION

\begin{tabular}{|l|c|c|c|c|c|c|c|c|}
\hline Rank & 1 & 2 & 3 & 4 & 5 & 6 & 7 & 8 \\
\hline Weight & 7 & 6 & 5 & 4 & 3 & 2 & 1 & 0 \\
\hline
\end{tabular}

Parameter average weights were calculated using the following equation:

$$
\mu_{i}=\frac{\sum_{j} M_{i, j}}{\sum_{i} \sum_{j} M_{i, j}}
$$

where $M_{i, j}$ is the weight of the parameter $i$ derived from Table II following the rank, assigned by expert $j$.

\section{RESULTS AND DISCUSSION}

Table III presents ranking of Table I parameters by the importance for the evaluation of the state financial security, summarised over the academic expert group. The figures in Table III indicate the number of experts, classifying corresponding parameter to the given rank: for example, 10 experts evaluated government debt to GDP ratio as having the higher importance with rank 1. Figures in Table III demonstrate noticeable scattering among expert opinions. For example, 10 experts assigned first rank to the government debt to GDP ratio, but 7 other experts - to the external debt to total debt ratio. Such a spread indicates that there may be two or more groups of academic experts having different opinions. This conclusion is supported by the low value of coefficient of concordance that for the academic expert group is equal to $W=0.35\left(\chi^{2}=62.8\right)$.

To analyse the distribution of opinions within the academic expert group, Spearman correlation coefficient was calculated for each pair of experts. The experts were considered as having close opinion if the value of the correlation coefficient exceeded 0.70. Experts with close opinion were re-grouped. As the result, two groups of academic experts were identified. 
For each of these groups, the coefficient of concordance was noticeably higher than for the whole pool of academic experts: $W=0.68\left(\chi^{2}=57.2\right)$ for the first group and $W=0.68$ $\left(\chi^{2}=56.8\right)$ for the second group.

TABLE III

PARAMETER RANKING BY ACADEMIC EXPERTS

\begin{tabular}{|c|c|c|c|c|c|c|c|c|}
\hline \multirow{2}{*}{ Indicator } & \multicolumn{7}{|c|}{ Rank } \\
\cline { 2 - 10 } & $\mathbf{1}$ & $\mathbf{2}$ & $\mathbf{3}$ & $\mathbf{4}$ & $\mathbf{5}$ & $\mathbf{6}$ & $\mathbf{7}$ & $\mathbf{8}$ \\
\hline Government debt / GDP & 10 & 11 & 1 & 2 & 2 & 1 & & \\
\hline Interest / Collected taxes & 1 & 4 & 6 & 7 & 4 & 2 & 1 & 2 \\
\hline Government budget deficit / GDP & 4 & 5 & 7 & 4 & 3 & 3 & 1 & \\
\hline Inflation rate & 1 & 3 & 4 & 4 & 3 & 6 & 2 & 4 \\
\hline $\begin{array}{c}\text { Long-term interest rate of the government } \\
\text { bonds }\end{array}$ & 1 & & 1 & & 6 & 2 & 13 & 4 \\
\hline $\begin{array}{c}\text { External government debt / Total } \\
\text { government debt }\end{array}$ & 7 & 1 & 6 & 2 & 6 & & 2 & 3 \\
\hline Government debt / Population & 1 & 2 & & 5 & 1 & 7 & 4 & 7 \\
\hline Money stock (M2) / GDP & 2 & 1 & 2 & 3 & 2 & 6 & 4 & 7 \\
\hline
\end{tabular}

Table IV summarises ranking of Table I parameters made by professionals. The opinions of professionals are in better agreement, and that is supported by high coefficient of concordance $W=0.75\left(\chi^{2}=36.6\right)$.

TABLE IV

PARAMETER RANKING BY PROFESSIONALS

\begin{tabular}{|c|c|c|c|c|c|c|c|c|}
\hline \multirow{2}{*}{ Indicator } & \multicolumn{7}{|c|}{ Rank } \\
\hline & $\mathbf{1}$ & $\mathbf{2}$ & $\mathbf{3}$ & $\mathbf{4}$ & $\mathbf{5}$ & $\mathbf{6}$ & $\mathbf{7}$ & $\mathbf{8}$ \\
\hline Government debt / GDP & 4 & 1 & 1 & & 1 & & & \\
\hline Interest / Collected taxes & 1 & 1 & 3 & 1 & & 1 & & \\
\hline Government budget deficit / GDP & 1 & 2 & 1 & 3 & & & & \\
\hline Inflation rate & & & & 2 & 2 & 2 & & 1 \\
\hline $\begin{array}{c}\text { Long-term interest rate of the government } \\
\text { bonds }\end{array}$ & 1 & 3 & 2 & & 1 & & & \\
\hline $\begin{array}{c}\text { External government debt / Total } \\
\text { government debt }\end{array}$ & & & & 1 & 2 & 3 & 1 & \\
\hline Government debt / Population & & & & & & & 4 & 3 \\
\hline Money stock (M2) / GDP & & & & & 1 & 1 & 2 & 3 \\
\hline
\end{tabular}

One has to note that opinions of both academic groups are significantly different from the one of the professionals' group, therefore, the groups could not be merged together and have to be considered separately.

Average parameter weights, defined by equation (2), were calculates separately using the data from each expert group. Calculations results are summarised in Table $\mathrm{V}$ and graphically illustrated in Fig. 1. For easier viewing, parameters in Fig. 1 were reordered to feature the weights derived from the professionals' data in the descending order.

From Fig. 1, one may conclude that experts-professionals treat long-term interest rate of the government bonds as a very important parameter, while academicians do not pay much attention to it. In turn, some academic experts, probably, overestimate the importance of the external debt to the total debt ratio.
TABLE V

PARAMETER AVERAGE WEIGHTS By EXPERT Groups

\begin{tabular}{|c|c|c|c|}
\hline Indicator & $\begin{array}{c}\text { Academic } \\
\text { 1st group }\end{array}$ & $\begin{array}{c}\text { Academic } \\
\text { 2nd group }\end{array}$ & Professionals \\
\hline Government debt / GDP & 0.223 & 0.214 & 0.224 \\
\hline Interest / Collected taxes & 0.121 & 0.173 & 0.188 \\
\hline Government budget deficit / GDP & 0.156 & 0.184 & 0.195 \\
\hline Inflation rate & 0.080 & 0.092 & 0.107 \\
\hline $\begin{array}{c}\text { Long-term interest rate of the } \\
\text { government bonds }\end{array}$ & 0.080 & 0.194 & 0.029 \\
\hline $\begin{array}{c}\text { External government debt / Total } \\
\text { government debt }\end{array}$ & 0.223 & 0.087 & 0.123 \\
\hline Government debt / Population & 0.018 & 0.020 & 0.091 \\
\hline Money stock (M2) / GDP & 0.098 & 0.036 & 0.042 \\
\hline
\end{tabular}

Since different expert groups have different opinions, they provide different set of parameter weights for the calculation of the consolidated state financial security indicator. In the present paper, all three sets were used for the calculation of the consolidated indicator on the basis of the Latvian data. The obtained indicator's values will be compared both between themselves and with the credit agency ratings.

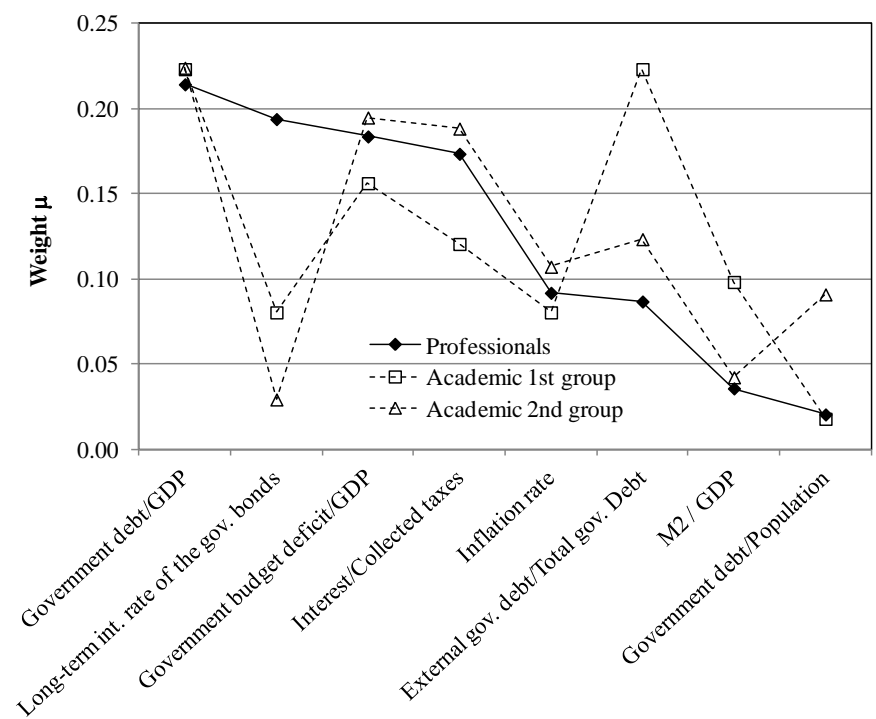

Fig. 1. Parameter weights by expert groups.

The data about the economy of Latvia and Eurozone countries for the period of $2000-2012$ were extracted from the Eurostat database [18].

\section{APPLICATION TO THE LATVIAN FINANCIAL SECURITY}

Fig. 2 summarises long-term external currency credit ratings, assigned to the Latvian economy over the period from 1997 to 2013 by most widely recognised credit agencies. It is important to note that ratings of Latvia still have not recovered from the crisis and have not reached the level of years $2004-$ 2007.

The most important risks that threaten the Latvian financial system stability are: 1) external risks due to extension of the Eurozone financial crisis and its negative impact on the growth in Europe and Latvia; 2) restricted payment abilities of 


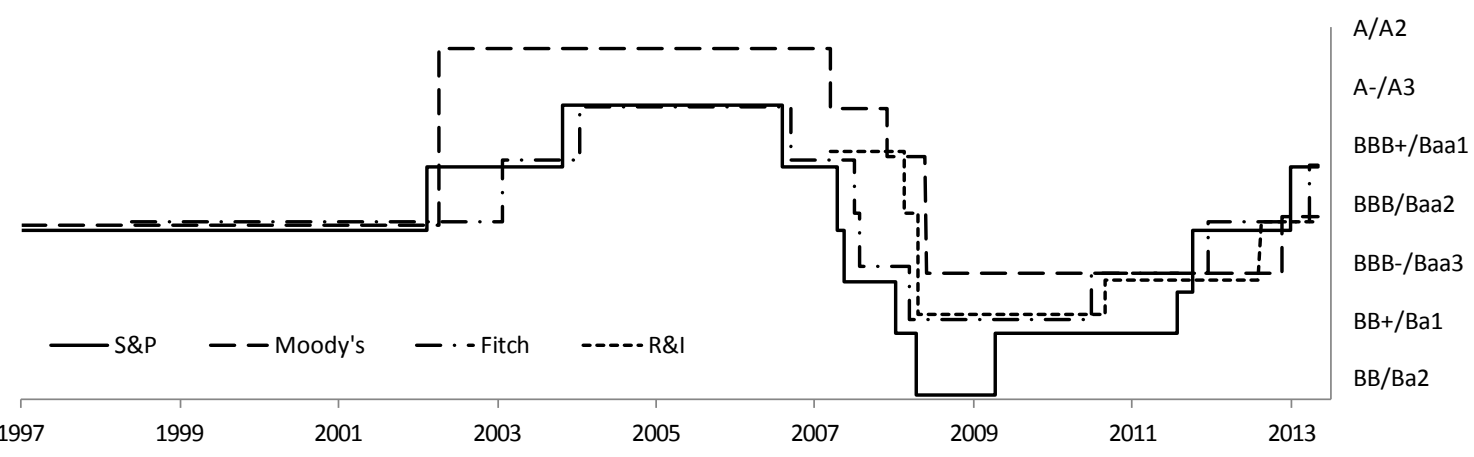

Fig. 2. Sovereign ratings of Latvia over the period $1997-2013$.

the households and still significant amount of overdue and restructured loans that may have a negative impact on the risks and profitability of the domestic credit institutions; 3 ) decrease in the demand for the saving securities due to reduced purchasing power of the population.

Deterioration of the fiscal situation in some of the Eurozone countries, development of the global state debt crisis, low world economic growth rate and long recession in the Eurozone are the factors that kept external risks high in 2012, too. Nevertheless, Latvia's credit rating increased from 2011 to 2013, which may raise some doubts whether the ratings reflects the actual situation.

For the sake of comparison with the calculated consolidated indicator, sovereign ratings were transformed using numerical scale following Semjonova [19]. In this scale, for example, Standard and Poor's rating AAA corresponds to 9.67, AA+ to 9.33 etc. down to rating $\mathrm{D}$ that corresponds to zero.

Fig. 3. demonstrates the trend in debt to GDP ratio for Latvia in 2000 - 2012. Despite severe crisis in 2008 - 2009, the value of debt never exceeded the recommended threshold of $60 \%$.

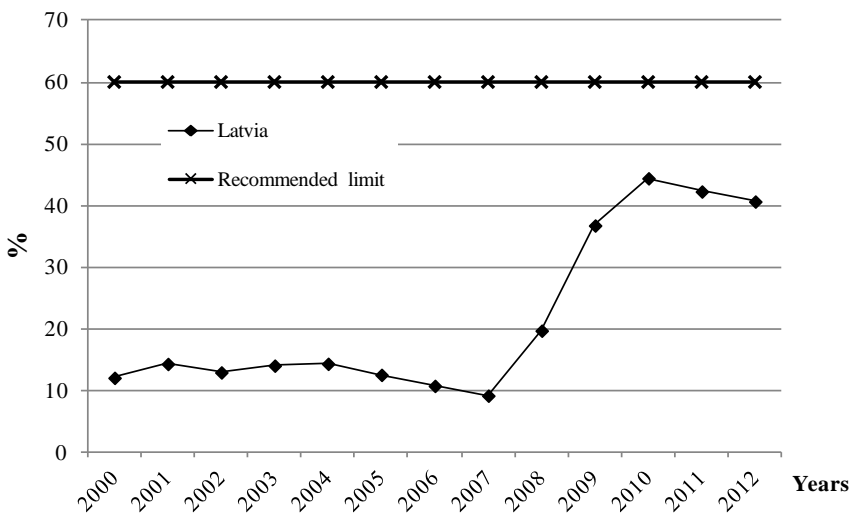

Fig. 3. Government debt to GDP ratio.

Debt service costs to collected taxes ratio (Fig. 4) were minimal in 2006 - 2007. From 2009, this parameter exceeded the recommended threshold, but there is a tendency for gradual decrease. Now the parameter is under the threshold.

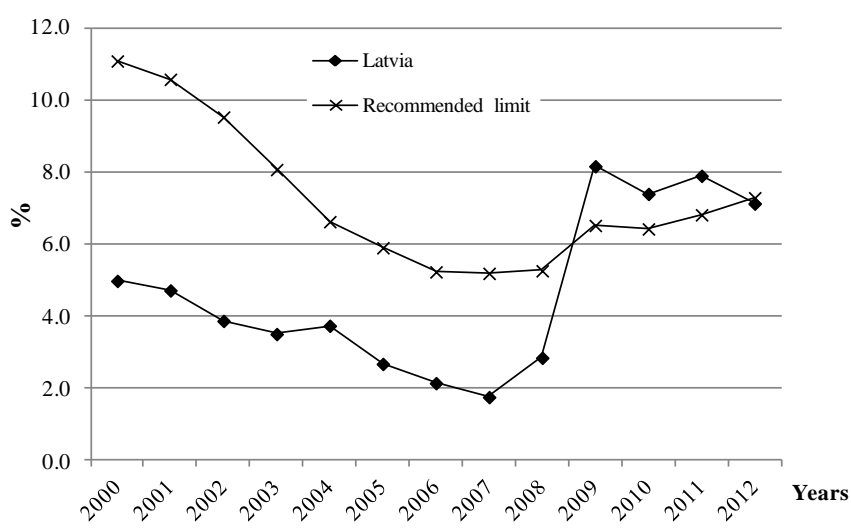

Fig. 4. Debt service costs to collected taxes ratio.

Latvia managed to keep government budget deficit below the recommended threshold of $3 \%$ up to the crisis year 2008 . From that moment, the deficit exceeded the threshold and strict budget consolidation policy allowed to drop the deficit below the threshold only in 2012 (Fig. 5).

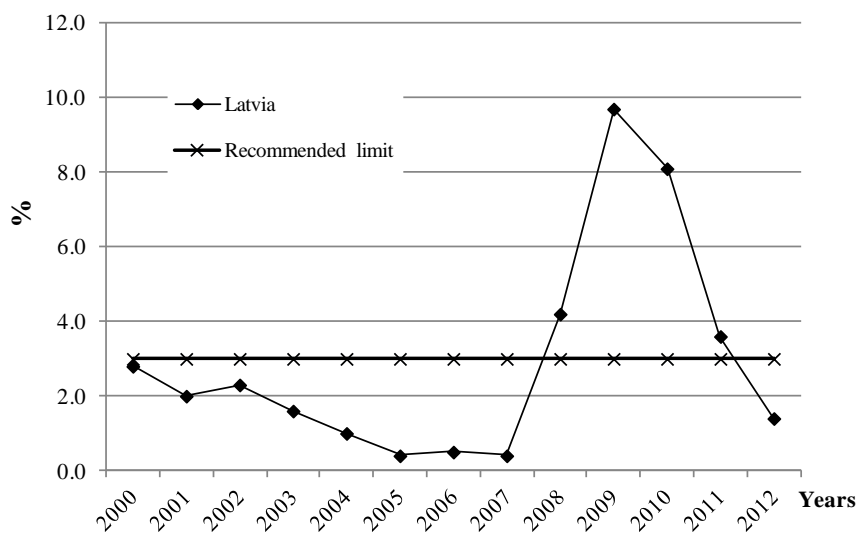

Fig. 5. Government budget deficit to GDP ratio.

The level of inflation in Latvia had exceeded the recommended threshold in 2005, peaked in 2008, but now is oscillating near the threshold value (Fig. 6). 


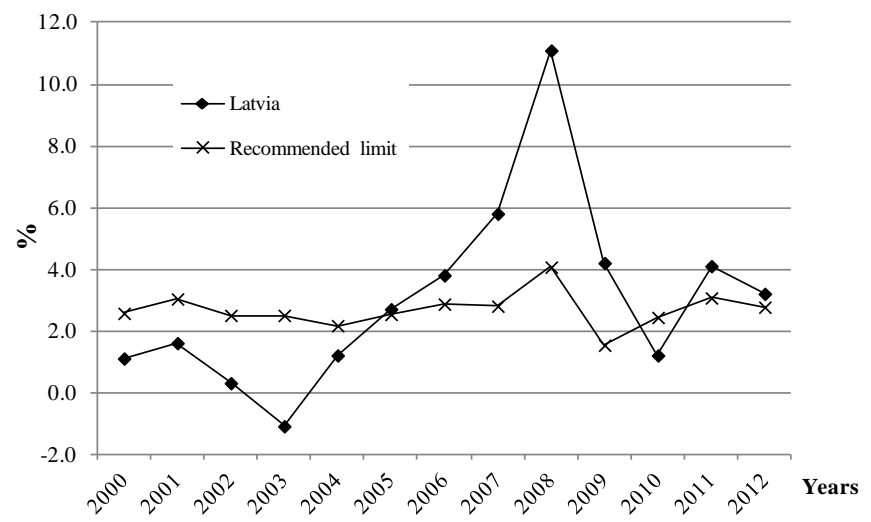

Fig. 6. Trend in the rate of inflation.

Starting from the year 2002, government bond long-term interest rate (Fig. 7) is steady below the threshold that may indicate relatively high level of creditors' confidence concerning Latvia's credibility.

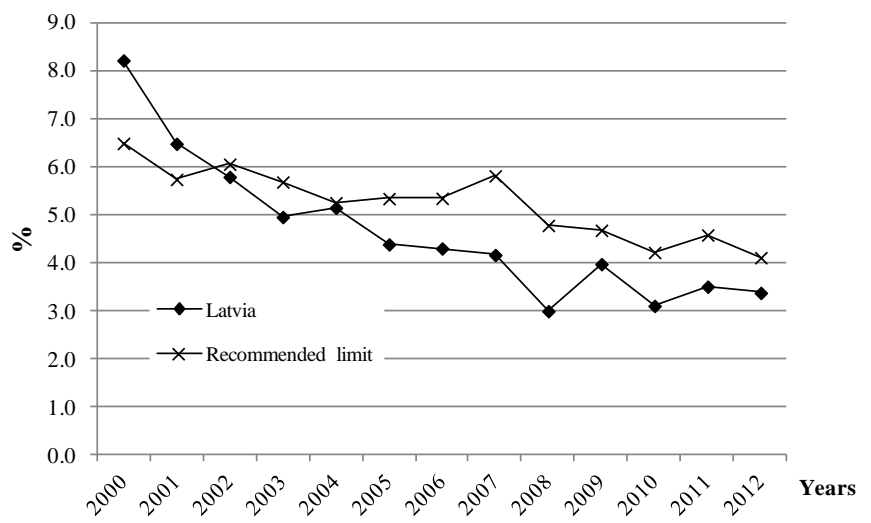

Fig. 7. Long-term interest rate of the government bonds.

The proportion of the external debt increased rapidly after 2009, thus the state had become more dependent on the external creditors (Fig. 8). The increase of the external debt proportion may indicate that domestic investors are not ready to purchase government securities, probably due to low trust in the government.

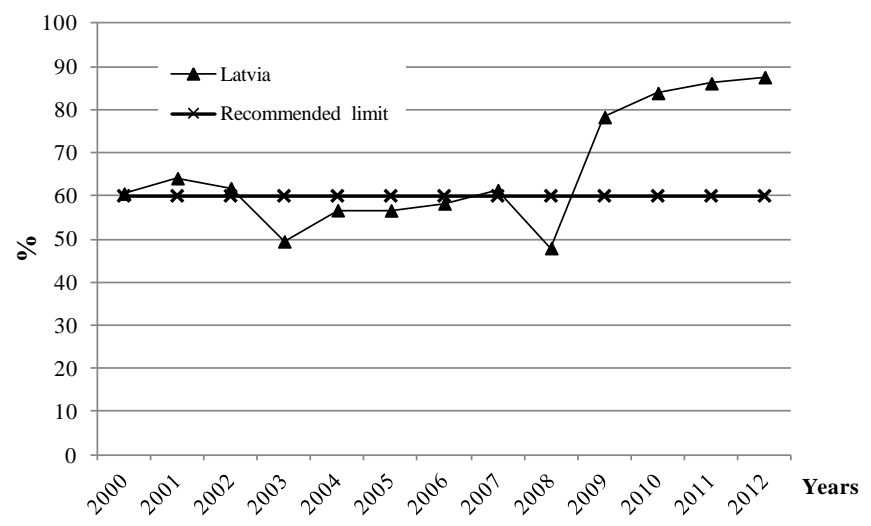

Fig. 8. External to total debt ratio.
Per capita debt (Fig. 9) had increased noticeably after 2008 and now still is over the threshold. Such a rapid growth is related not only to active government borrowing, but also with the rapid depopulation due to emigration: only in $20110.4 \%$ of economically active inhabitants emigrated [20]. Overall, in the last 15 years the population of Latvia decreased by 500 thousand people.

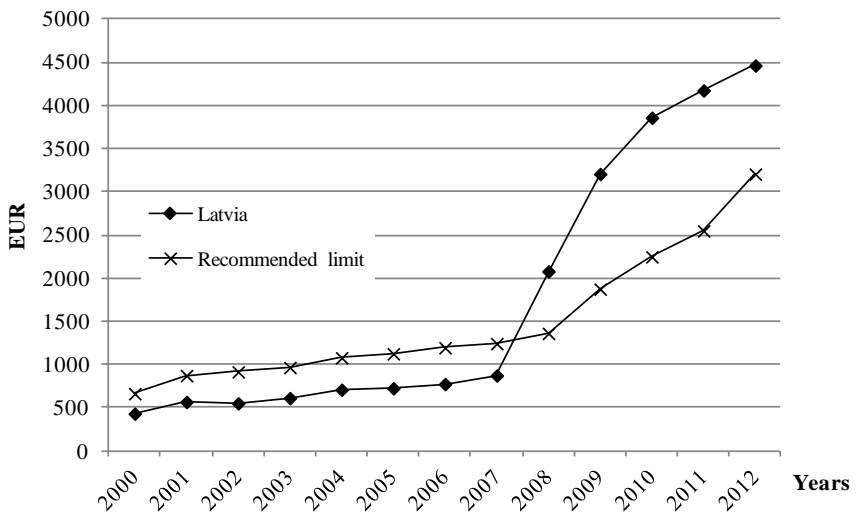

Fig. 9. Government debt to population ratio

The money stock (Fig. 10) in Latvia is well below the recommended threshold.

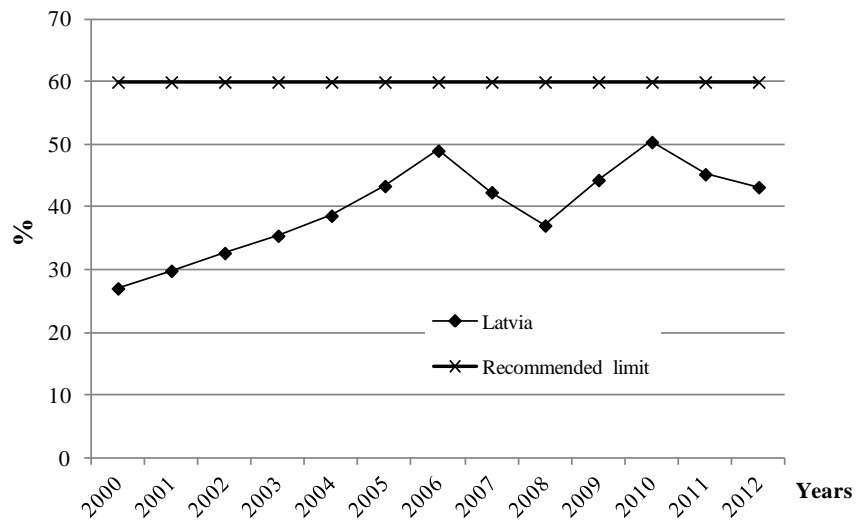

Fig. 10. Money stock M2 to GDP ratio.

Data from Fig. 3 - Fig. 10 were used to calculate the consolidated indicator from equation (1), using the set of weights, provided by three groups of experts. Calculation results demonstrated in Fig. 11. Despite the noticeable difference in the assignment of weights by different groups of experts (Fig. 1), the resulting indicator values nearly coincide. Thus, one may suppose that evaluation of the financial security by means of the proposed consolidated indicator weakly depends on the relative importance of the contributing parameters.

Correlations between calculated consolidated indicator $X$ and numerically expressed sovereign ratings are presented in Fig. 12. Independently on which set of parameter weights was selected for the calculations, resulting $X$ values are in reasonable agreement with the credit ratings - there is a good negative correlation between S\&P, R\&I, Fitch ratings and indicator $X$. 


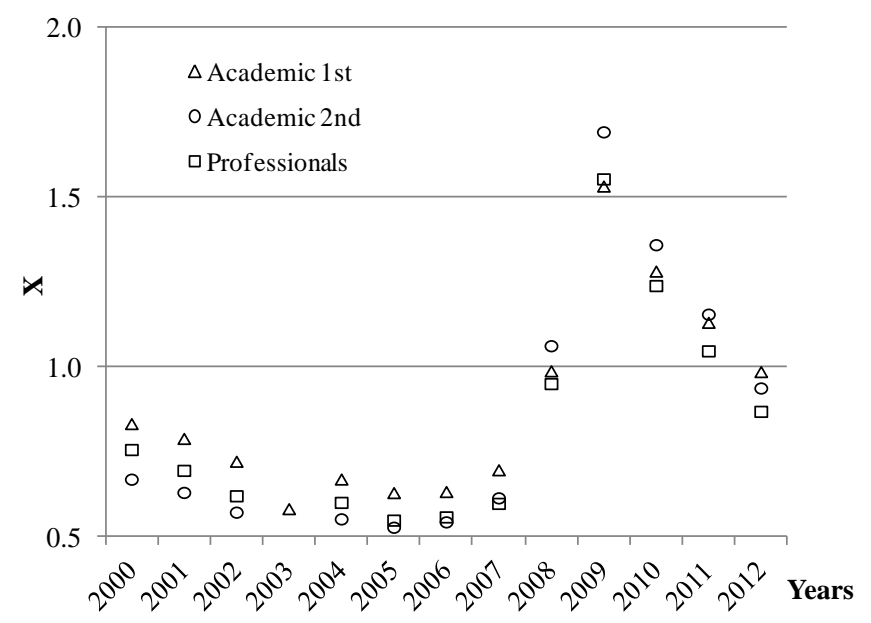

Fig. 11. Values of the consolidated indicator of the state financial security, calculated using weight coefficients from different expert groups.

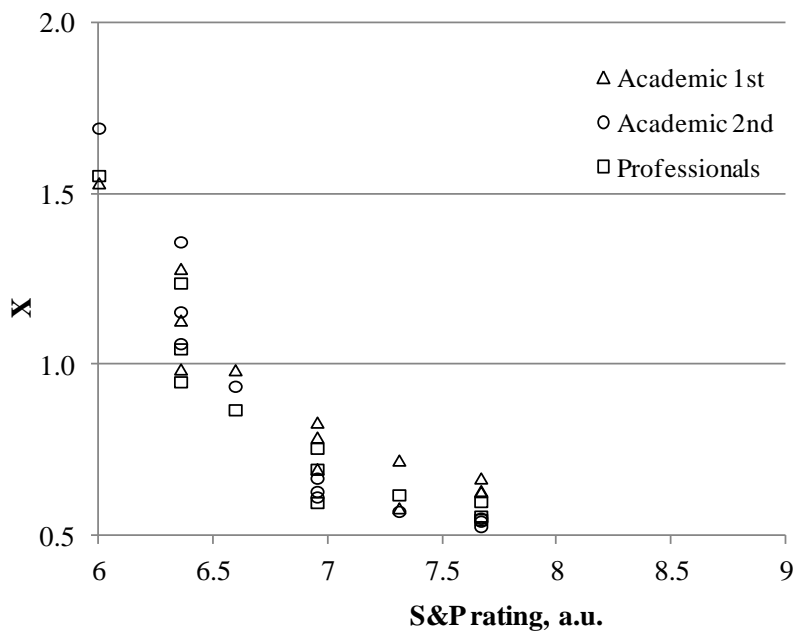

a

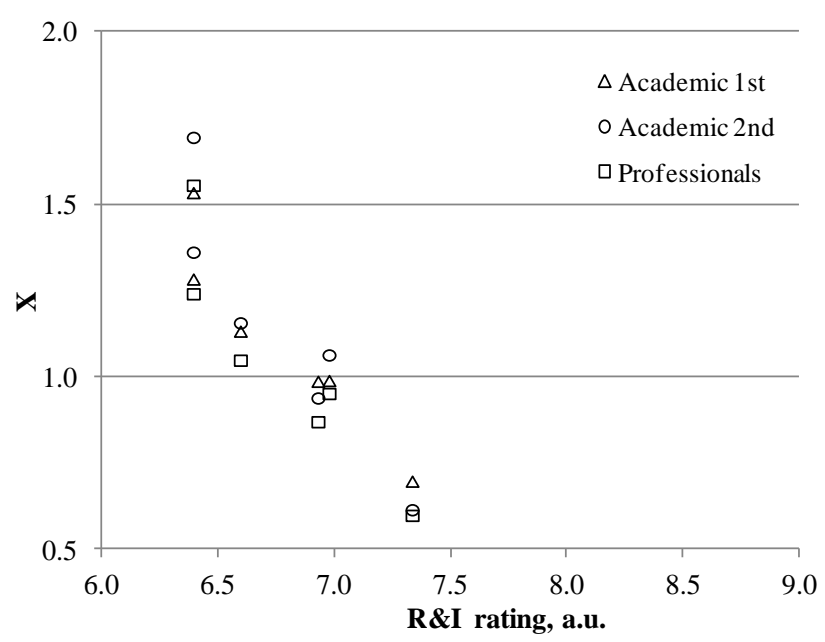

The relationship between $X$ and these ratings are nearly linear in the range of low ratings up to rating-related values of $7-7.5$ that corresponds to the $\mathrm{BBB}+\mathrm{S} \& \mathrm{P}$ rating. For higher values of the sovereign ratings, parameter $X$ saturates at the level of 0.6 - see, for instance, Fig. 12.d. This indicates that rating agencies give more optimistic prognosis for high-rating countries than indicator $X$ does, and that financial stability of these countries is overestimated.

The correlation between consolidated indicator $X$ and Moody's rating is not so good, which may require additional exploration.

It should be noted that the correlation diagrams are nearly the same for all used sets of contributing parameter weight factors. This supports the conclusion about independence of $X$ on the relative importance of the parameters. Practically this means that weight factors presented in Table $\mathrm{V}$ may be averaged over the expert groups and thus one set of weight factors will be derived.
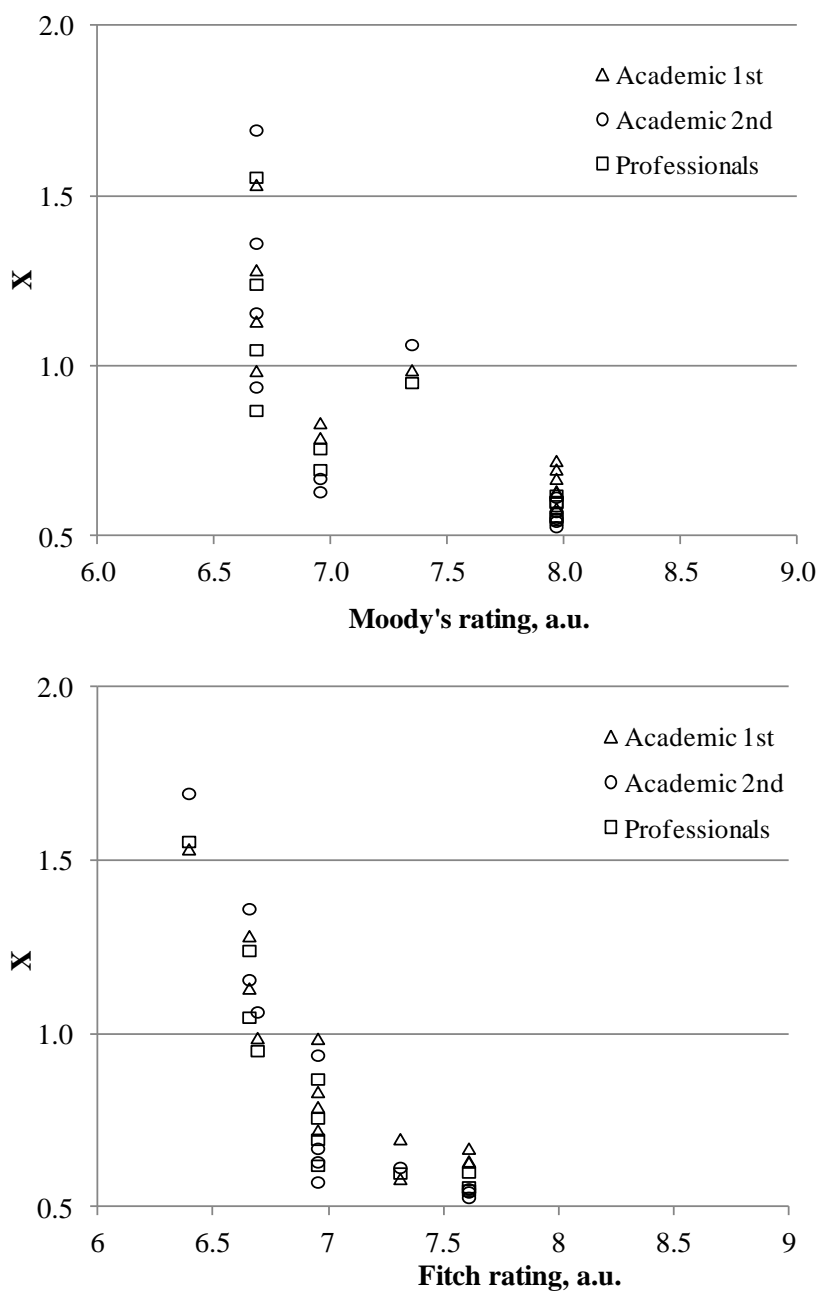

Fig. 12. Correlation between consolidated financial security indicator $X$ and numerically expressed sovereign ratings issued by a) Standard and Poor, b) Moody c) R\&I and d) Fitch credit rating agencies. 


\section{CONCLUSION}

The present paper proposed a consolidated indicator for the evaluation of the state financial security. The indicator is based on the eight economic and financial parameters: government debt to GDP ratio; debt service costs to the collected taxes ratio; government budget deficit to GDP ratio; inflation rate; long-term interest rate of the government bonds; external government debt to the total government debt ratio; per capita government debt; money stock (M2) to GDP ratio. For the data on Latvia, the consolidated indicator correlates well with the ratings assigned by internationally recognized credit rating agencies. This correlation is the best for the low credit ratings. In the range of higher ratings $-\mathrm{S} \& \mathrm{P} \mathrm{BBB}+$ and higher - consolidated indicator gives less optimistic evaluation.

The analysis of the expert pool opinions demonstrated that there are different points of view on the relative importance of different economic parameters for the state financial security. The opinion of the professionals differs from the one of the academic experts; moreover, there are two distinct groups within academic society. The main disagreement concerns the role of long-term government bond interest rate and the role of the external debt proportion. Both academic groups tend to underestimate the former and at least one academic group overestimates the latter.

Further development of the proposed indicator needs its validation with the use of the data from other countries data, especially those in pre- default conditions.

\section{REFERENCES}

[1] D. Furceri, A. Zdzienicka, "How costly are debt crises?" Journal of International Money and Finance, 2012, vol. 31 pp. 726-742. http://dx.doi.org/10.1016/j.jimonfin.2012.01.012

[2] B. S. De Paoli, G. Hoggarth, V. Saporta, "Costs of sovereign defaults," Bank of England Financial Stability, no. 1, July 2006.

[3] M. De Broeck, "The financial structure of government debt in OECD countries: An examination of the time-consistency issue," Journal of Monetary Economics, 1997, vol. 39, no. 2, pp. 279-301. http://dx.doi.org/10.1016/S0304-3932(97)00013-5

[4] H. Hughes, "Debt and development: The role of foreign capital in economic growth," World Development, 1979, vol. 7, no. 2, pp. 95-112. http://dx.doi.org/10.1016/0305-750X(79)90026-3

[5] F. Drudi and R. Giordano, "Default risk and optimal debt management," Journal of Banking and Finance, 2000, vol. 24, no. 6, pp. 861-891. http://dx.doi.org/10.1016/S0378-4266(99)00110-7

[6] M. P. Dooley, "Debt management and crisis in developing countries," Journal of Development Economics, 2000, vol. 63, no. 1, pp. 45-58. http://dx.doi.org/10.1016/S0304-3878(00)00099-7
[7] A. Afonso, J. T. Jalles, "Growth and Productivity: The Role of Government Debt," International Review of Economics and Finance, 2013, vol. 25, pp. 384-398. http://dx.doi.org/10.1016/j.iref.2012.07.004

[8] European Central Bank, Analysing government debt sustainability in the euro area. Monthly Bulletin, Apr. 2012, pp. 55-70, [Online]. Available: https://www.ecb.europa.eu/ pub/pdf/mobu/mb201204en.pdf

[9] Moody's, "Sovereign Bond Ratings, Rating Methodology," 2012. [Online]. Available: www.moodys.com/researchandratings/ratingmethodologies. [Accessed: July 14, 2012].

[10] Fitch Rating, "Rating methodology," 2012. [Online]. Available: http://www.fitchratings.com/gws/en/sector/overview/sovereigns [Accessed: Aug. 13, 2012].

[11] Standard\&Poor's, "Sovereign ratings," 2012. [Online]. Available: www.standardandpoors.com/ratings/sovereigns/ratings at 02.06.2012.

[12] Japan Credit Rating Agency, "Rating methodology," 2012. Available: http://www.jcr.co.jp/english/ [Accessed: Aug. 18, 2012].

[13] National security conception LR Saeima, Latvijas vēstnesis, in Latvian, (Nacionālās drošības koncepcija: LR Saeimas ziņojums), 2012, [Online]. Available: http://www.likumi.lv.

[14] Financial stability review Bank of Latvia (Finanšu stabilitātes pārskats / Latvijas Banka), 2012. [Online]. Available: http://www.bank.lv /publikacijas/finansu-stabilitates-parskats [Accessed: Apr. 15, 2012]

[15] K. Ketners, A. Krastiņš, S. Zvidriņa, "Principles of evaluation of the Latvia financial policy and state security criteria," Economics and Business, ERU Scientific papers, 2007, Riga, vol. 14, pp. 34-42.

[16] M. G. Kendall, S. B. Babington, "The Problem of m Rankings," The Annals of Mathematical Statistics, vol. 10, no. 3, pp. 275-287, 1939, http://dx.doi.org/10.1214/aoms/1177732186

[17] P. Legendre, "Species Associations: The Kendall Coefficient of Concordance Revisited," Journal of Agricultural, Biological and Environmental Statistics, 2005, vol. 10, no. 2, pp. 226-245. http://dx.doi.org/10.1198/108571105X46642

[18] Eurostat Data base Government Deficit and Debt, 2013. [Online]. Available: http://epp.eurostat.ec.europa.eu/ [Accessed: Sept. 02, 2013].

[19] N. Semjonova, "Structure of the national debt, credit rating and state financial security," Proceedings of the 53th International Riga Technical University Conference ,Scientific Conference on Economics and Enterpreneurship, " SCEE'2012, Oct. 12-16, 2012, Riga, RTU, p. 6.

[20] Central Statistics Bureau. Number of Inhabitants. [Online]. Available: http://www.csb.gov.lv/statistikas-temas/iedzivotaji-galvenie-raditaji30260.html [Accessed: Mar. 15, 2013]. (In Latvian: Centrālās statistikas pārvalde, 2013. Iedzīvotāju skaits).

Nadezhda Semjonova received the degree of Master of Business Administration in 1997 and the Doctoral degree in Business Management in 2012 from the Faculty of Engineering Economics and Management, Riga Technical University.

Since 2010, she has been Assistant Professor in a professional study program with the Department of Finance, RTU. From 2007 to 2010, she was Assistant Professor with the Department of Business Management and Human Resources, RTU. From 1999 to 2007, she was a Lecturer with RTU. From 1994 to 1998, she was Chief Accountant-Auditor with the State Forest Service, State Inspection of Forest and Hunting.

E-mail: Nadezda.Semjonova@rtu.lv. 